\title{
Foreword - Raising climate ambition: a resolution for a green new deal
}

\section{Professor Matthew Rimmer*}

\section{INTRODUCTION}

Professor Abbe Brown's book Intellectual Property, Climate Change and Technology represents a heartfelt cry to increase climate ambition.

Brown is a legal academic based at the University of Aberdeen, Scotland, where she is a member of the Centre for Commercial Law and the Centre for Energy Law. Her work spans intellectual property, commercial law, human rights, competition policy, and climate law. Brown has previously published a monograph, Intellectual Property, Human Rights and Competition: Access to Essential Innovation and Technology in 2012, ${ }^{1}$ an edited collection, Environmental Technologies, Intellectual Property and Climate Change in 2013, ${ }^{2}$ and a Research Handbook on Intellectual Property and Creative Industries edited with Charlotte Waelde in 2018. ${ }^{3}$ Her latest book represents both a consolidation of her past research interests and an expansion into new territory,

* Professor Matthew Rimmer (BA/LLB ANU, Phd UNSW) is a Professor in Intellectual Property and Innovation Law at the Faculty of Law in the Queensland University of Technology ('QUT'). He is a leader of the QUT Intellectual Property and Innovation Law research program; and a member of the QUT Digital Media Research Centre (QUT DMRC), the QUT Australian Centre for Health Law Research (QUT ACHLR), and the QUT International Law and Global Governance Research Program (QUT IL GG). Save where otherwise indicated, all links were accessed February 2019.

1 Abbe EL Brown, Intellectual Property, Human Rights and Competition: Access to Essential Innovation and Technology (Edward Elgar Publishing 2012).

2 Abbe EL Brown, Environmental Technologies, Intellectual Property and Climate Change (Edward Elgar Publishing 2013).

3 Abbe EL Brown and Charlotte Waelde (eds), Research Handbook on Intellectual Property and Creative Industries (Edward Elgar Publishing 2018). 
being an undertaking to consider ways and meanings of increasing climate ambition - through judicial decision making, administrative procedure, and legislative action. The work is particularly focused upon the role of technology in the debate over climate change.

Her new work is in the vanguard of a new field of scholarship which seeks to provide policy solutions for the technology problems of the climate crisis. A number of Nobel Laureates in economics have been grappling with the problem of research, development, and transfer of clean technologies in order to tackle the climate crisis. Joseph Stiglitz has been investigating how intellectual property laws could be recalibrated and redesigned to better account for sustainable development and climate change. ${ }^{4}$ Stiglitz and his collaborators have argued: 'A substantial recalibration of the international approach to Intellectual Property Rights is required to ensure the advancement of the standards of living and well-being of the entire world.' 5 In their view, 'As the world continues to move towards greater integration and becomes more interdependent and faces up to the pressing challenge posed by our co-dependencies on each other, including global public health and climate change, these reforms will become more urgent.' 6

Another Nobel Prize winner, William Nordhaus, has also been focused upon the best public policy options to promote the adoption of clean technologies. ${ }^{7}$ In his 2018 Nobel Lecture in Economics, Nordhaus stressed that 'people must understand the gravity of global warming', engage in 'intensive research' and resist 'false and tendentious reasoning'. ${ }^{8} \mathrm{He}$ insisted that '[n]ations must raise the price of $\mathrm{CO}_{2}$ and other greenhouse-gas emissions'. ${ }^{9} \mathrm{He}$ also maintained that 'policies must be global and not just national or local' 10 and believes that 'the best hope for

4 Dean Baker, Arjun Jayadev and Joseph Stiglitz, Innovation, Intellectual Property, and Development: A Better Set of Approaches for the 21st Century (AccessIBSA 2017) http://cepr.net/images/stories/reports/baker-jayadev-stiglitzinnovation-ip-development-2017-07.pdf.

5 Baker, Jayadev and Stiglitz n4.

6 Baker, Jayadev and Stiglitz n4.

7 William Nordhaus, The Climate Casino: Risk, Uncertainty, and Economics for a Warming World (Yale University Press 2013).

8 William Nordhaus, 'Nobel Prize Lecture' (8 December 2018) https://www. nobelprize.org/prizes/economic-sciences/2018/nordhaus/lecture/ and https://www. youtube.com/watch? $\mathrm{v}=\mathrm{h} 1 \mathrm{RkSuAs} 03 \mathrm{Q}$.

9 Nordhaus $\mathrm{n} 8$.

10 Nordhaus n8. 
effective coordination is a climate club'. ${ }^{11}$ In his view, 'rapid technological change in the energy sector is essential'. ${ }^{12}$

In this context, Brown seeks to address one of the profound challenges of our time - namely, achieving a just transition to a low-carbon economy to address the wicked global problems of climate change. This foreword considers three key dimensions of the contribution of this book. First, it explores the work as a response to the need for global climate action in the wake of the Paris Agreement 2015. Second, the foreword examines how the book considers new legal, regulatory, and administrative frameworks to address climate change. Third, it examines climate litigation as a means of encouraging government and corporate action in respect of climate change. Brown seeks to push for greater climate ambition in international agreements, in national policy, and in the courts.

\section{INTERNATIONAL LAW}

This book responds to the passage of the Paris Agreement 2015 and the need for countries to fulfil their pledges and raise their climate ambitions. ${ }^{13}$

The Heads of State Declaration for Greater Climate Ambition 2018 is a remarkable statement on the need for greater climate ambition. ${ }^{14}$ The document notes that 'current measures taken by the international community, as expressed in nationally determined contributions (NDCs) to the Paris Agreement, are not sufficient to reach the long-term goals set out in the Paris Agreement'. ${ }^{15}$ The Declaration insists that '[m]ore has to be done - and action needs to be quick, decisive and joint'. ${ }^{16}$ The Declaration maintains: 'Let us take the manifold opportunities and measures to combat climate change forward and shape a positive future for our planet.' ${ }^{17}$

\footnotetext{
11 Nordhaus n8.

12 Nordhaus n8.

13 Paris Agreement to the United Nations Framework Convention on Climate Change, opened for signature 12 December 2015 (entered into force 4 November 2016) (in UNFCCC, Report of the Conference of the Parties on its Twenty-First Session, Addendum, UN Doc FCCC/CP/2015/10/Add.1, 29 Jan 2016).

14 Heads of State Declaration for Greater Climate Ambition, November 2018, https://www.bundespraesident.at/aktuelles/detail/news/initiative-for-more-climateambition/.

15 Heads of State Declaration n14 [7].

16 Heads of State Declaration n14 [7].

17 Heads of State Declaration n14 [15].
} 
In December 2018 the United Nations Secretary General Antonio Guterres discussed his objectives in terms of the implementation of the Paris Agreement 2015. ${ }^{18}$ He emphasized: 'The Paris Agreement is not a piece of paper.' ${ }^{19}$ In his mind, '[i]t is a historic compact among nations, a compact to ensure our survival' ${ }^{20}$ Guterres has emphasized the need for national governments and other actors to raise their climate ambitions: 'Countries need notably to fulfil their pledges. They also need to raise their ambition. We need clear moves not only by national governments but also by other actors such as subnational governments, businesses and investors.' 21

Guterres has also stressed the need for genuine transformative action in the real economy: 'We need national governments to play a crucial role in each of the robust coalitions which will deliver concrete transformative outcomes.' $22 \mathrm{He}$ has commented: 'I invite all governments, businesses, sources of finance - public and private - and civil society organizations to join in the preparatory process to raise real ambition and transform the real economy.'23 Guterres has also highlighted the importance of community support for climate action: 'We need to harness their energy, invention and political power to raise climate ambition.'24

The President of Ireland, Michael D. Higgins, has also been similarly concerned about questions of climate change, climate vulnerability, and climate justice. At the 2018 Virtual Summit of the Climate Vulnerable Forum, Higgins spoke of climate change as 'the greatest challenge of our age'. ${ }^{25} \mathrm{He}$ explained that climate change was truly a global issue, stressing that 'no continent, no nation, and no people can claim that they are immune to the effects of climate change' 26 and maintained: 'That is why those nations most responsible for the accumulation of greenhouse gases in our atmosphere owe not only a duty of solidarity, but of justice,

18 Antonio Guterres, 'Remarks on the 2019 Climate Summit', United Nations Secretary General, Katowice, 4 December 2018, https:/www.un.org/sg/en/ content/sg/speeches/2018-12-04/remarks-2019-climate-summit.

19 Guterres n18.

20 Guterres n18.

21 Guterres n18.

22 Guterres n18.

23 Guterres n18.

24 Guterres n18.

25 President Michael D. Higgins, 'Statement on Climate Change to the Climate Vulnerable Forum 2018' (22 November 2018) https://president.ie/en/ media-library/news-releases/statement-on-climate-change-to-the-climate-vulnerableforum-2018.

26 Higgins n25. 
to those who will bear the heaviest and most immediate burden of climate change and also, of course, to future generations. 27 He emphasized the need for solidarity and fidelity in honouring the pledges made under the Paris Agreement 2015. He stressed that nation states needed to demonstrate their commitment, "not only through a just transition to a carbon-free economy, but by the mobilisation of finance, resources and science and technology and, above all, their being made available for climate adaptation'. ${ }^{28}$ Higgins emphasized the need for the achievement of climate justice: 'Put simply, it will demand a renewed and visibly active dedication to justice, equality, and solidarity, and it will require an effort equal to the dangers that the most vulnerable nations on our planet now confront.' 29

Brown's book is animated by a fervid desire for heightened climate ambition. In many ways, the book seeks to uncover public policy strategies, which would help fulfil the targets of the Paris Agreement 2015, and further raise future targets.

Former President of Ireland and UN Special Envoy on Climate Change Mary Robinson has also been active in connecting climate change and human rights. Her 2018 book Climate Justice has sought to ground discussions of climate justice in the lived experiences of frontline and vulnerable communities. ${ }^{30}$ She remains concerned about the implementation of the Paris Agreement 2015: 'While Paris remains an unprecedented success, it is also a fragile foundation for action.' ${ }^{31}$ She also argues that there is scope for innovative policy solutions for the crisis of climate change and is firmly of the view that there is a need to bring together climate change and sustainable development: 'As we pursue this new stage of bold action, we will succeed only if we recognise that the struggle to combat climate change is inextricably linked to tackling poverty, inequality, and exclusion.' 32 She suggests: 'If we give voice to those who have been marginalised and shut out, our policies and projects - both public and private - will tackle the root causes of both climate change and inequality.' 33

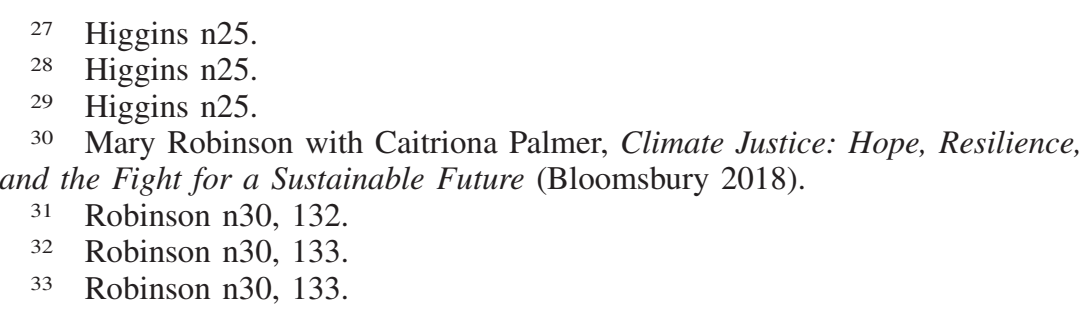


French President Emmanuel Macron has been a key figure in the debate over climate change. ${ }^{34} \mathrm{He}$ has beseeched nation states to abide by the Paris Agreement 2015: 'When it comes to climate disruption, there are no free-riders or easy solutions either.' ${ }^{35} \mathrm{He}$ was distressed by the Trump administration withdrawing from the Paris Agreement: 'Those who undermine collective action are only exposing themselves to a greater degree. ${ }^{36} \mathrm{He}$ emphasized that there was a need to account for questions of inequality in tackling global crises like climate change: 'We owe an answer to the 700 million children who live in the regions most exposed to the effects of climate change, who are the victims of floods, drought, rising waters, diminishing resources. ${ }^{37}$

This new book by Brown seeks to bring together considerations of international law, intellectual property, technology transfer, human rights, and climate justice.

\section{PUBLIC POLICY}

There is a strong focus in the book on the theoretical underpinnings of intellectual property law and policy in relation to the environment, biodiversity, and climate change. Philosopher Stephen Gardiner has commented that many stock standard theories - such as cost-benefit analysis; the precautionary principle; the notion of the free-rider; and the vision of commons - are ill-adapted and unsuited to climate change. ${ }^{38} \mathrm{He}$ has called for the development of new theoretical frameworks, which can better explain the complexities of climate change. In this context, Brown has sought to consider existing theoretical frameworks in respect of intellectual property, and their adequacy for dealing with environmental problems. She discovers that there has been a failure of traditional intellectual property theories - such as the rewards approach, natural rights, and Lockean conceptions of labour - to adequately account for

34 Emmanuel Macron, 'Speech to the United Nations General Assembly' (25 September 2018) https://www.diplomatie.gouv.fr/en/french-foreign-policy/unitednations/events/united-nations-general-assembly-sessions/unga-s-73rd-session/ article/united-nations-general-assembly-speech-by-president-emmanuel-macron25-09-18.

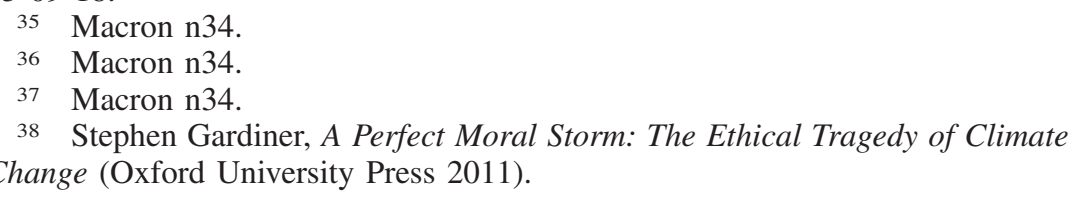


nature. Brown maintains that there is a need to better connect theories of intellectual property with environmental law and regulation.

In her scholarship, Brown has been concerned about the current fragmented and conflicted state of the discipline of climate law. There is an effort within the work to integrate and synthesize various disparate parts of climate law and policy into a unified whole. Brown remains hopeful of the possibility of better aligning the fields of intellectual property, innovation policy, and climate law. She stresses that there are common objectives in terms of the various disciplines. In an effort to resolve disciplinary border conflicts, this book seeks to ground its discussions in terms of case studies and scenarios to help identify potential points of conflict and friction. This book seeks to develop, foster, and build an interdisciplinary interpretative community in respect of climate law and policy.

In this book, Brown investigates new regulatory pathways and legal frameworks to address climate change. She considers both current strategies to address climate change and future tools that could be used in the field. Brown is particularly interested in the dominant varieties of intellectual property, such as patent law, designs law, trademark law, copyright law, and trade secrets. She is also equally concerned about the role of innovation policy and the settings for environmental and climate laws. In the course of the book, Brown covers a wide range of jurisdictions.

In terms of its geographical scope, the book has a particular focus upon intellectual property, renewable energy, and climate change in Scotland, the United Kingdom, and the European Union.

In 2019 the First Minister of Scotland, Nicola Sturgeon, has discussed the leadership of Scotland in realizing the goals of the Paris Agreement 2015: 'We aim to be carbon neutral by 2050, and we want to reach net zero of all greenhouse gas emissions as soon as we possibly can.' 39 Sturgeon explains why Scotland, in particular, is well placed to take climate action: 'Well, partly its political will - and we've got great consensus across the political spectrum in Scotland.' ${ }^{40}$ She emphasized the natural assets of Scotland in terms of renewable energy: 'We also have massive renewable energy potential and that has allowed us already to reach a position where around 70 percent of our electricity comes from

39 Nicola Sturgeon, 'Talking Climate and Health: First Minister of Scotland' (Climate Reality Project 19 February 2019) https://t.co/KgtpoisyY4.

40 Sturgeon $n 39$. 
renewable sources.' ${ }^{41}$ Sturgeon was hopeful that Scotland would provide a leadership role for other nations: 'So we're blessed with the natural resources, and coupling that with the political will means that we're able to go faster than many others and that helps us to encourage others across the UK, across Europe, and further afield to follow on.' ${ }^{42}$ Sturgeon has also emphasized that Scotland has been the first country anywhere in the world to establish a climate justice fund. She said it was the duty of governments to take such action: 'So it's right and incumbent on developed countries that we put climate justice at the heart of everything we do.' 43

In this context, Brown's work represents a shining example of Scotland's climate ambition. Her book looks for ways and means to amplify Scotland's aspirations to become a leader in clean technologies.

The European Union has sought to play a leadership role in respect of climate action. ${ }^{44}$ European Commission President Jean-Claude Juncker has promised substantive action: 'In the next financial period from 2021 to 2027, every fourth euro spent within the EU budget will go towards action to mitigate climate change. ${ }^{\prime}{ }^{4} \mathrm{He}$ has expressed concern about climate denial and misinformation - particularly by the Trump administration. ${ }^{46}$

As was well as withdrawing the United States from the Paris Agreement 2015, the Trump administration has sought to systematically deregulate environmental and climate laws during its term of government. There have nonetheless been efforts by states and cities in the United States to take climate action in spite of the climate inaction of the federal government. In reaction to Trump's decision to withdraw the United States from the Paris Agreement, Governors Andrew Cuomo, Jay Inslee, and Jerry Brown created the United States Climate Alliance. ${ }^{47}$ This coalition is 'committed to the goal of reducing greenhouse gas emissions consistent with the goals of the Paris Agreement 2015'. ${ }^{48}$ In its view, '[s]mart, coordinated state action can ensure that the United States

\footnotetext{
41 Sturgeon $n 39$.

42 Sturgeon n39.

43 Sturgeon $n 39$.

44 Clare Roth, 'Swedish student leader wins EU pledge to spend billions on climate' (Reuters 21 February 2019) https://www.reuters.com/article/us-climate change-teen-activist/swedish-student-leader-wins-eu-pledge-to-spend-billions-onclimate-idUSKCN1QA1RF.

45 Roth n44.

46 Roth n44.

47 United States Climate Alliance https://www.usclimatealliance.org/ accessed 1 May 2018.

48 United States Climate Alliance n47.
} 
continues to contribute to the global effort to address climate change' ${ }^{49}$ Former New York Mayor Michael Bloomberg and Carl Pope have promoted the role of cities, businesses, and citizens in climate action. ${ }^{50}$ The C-40 initiative has sought to provide for an international network of mega-cities to take action in respect of climate change.

In the United States Congress, Alexandra Ocasio-Cortez and the Sunrise Movement have promoted the Green New Deal as a package of policy options designed to promote a just transition to a renewable economy. ${ }^{51}$ The resolution calls for the creation of a Green New Deal with the goals of achieving net-zero greenhouse gas emissions; establishing high-wage jobs and ensuring economic security for all; investing in infrastructure and industry; securing a sustainable environment for all; and promoting justice and equality. The resolution asks for a 10-year mobilization effort - with a range of activities to boost these goals. The resolution has been co-sponsored by 68 Democrat politicians. Naomi Klein has argued that the policy package represents an ambitious effort to respond to the climate crisis. ${ }^{52}$ Jeffrey Sachs of Columbia University maintains that the Green New Deal is feasible and affordable. ${ }^{53}$ Likewise, progressive civil society organizations have supported a Green New Deal. ${ }^{54}$ Some establishment Democrats - such as Dianne Feinstein - have also been discomforted by the movement for the Green New

49 United States Climate Alliance n47.

50 Michael Bloomberg and Carl Pope, Climate of Hope: How Cities, Businesses, and Citizens Can Save the Planet (St Martin's Press 2017).

51 Recognizing the Duty of the Federal Government to Create a Green New Deal, H.Res. 109-116th Congress (2019-2020) https://www.congress.gov/bill/ 116th-congress/house-resolution/109/text.

52 Naomi Klein, 'The Battle Lines Have Been Drawn on the Green New Deal' (The Intercept 14 February 2019) https://interc.pt/2IaadsV.

53 Jeffrey Sachs, 'Green New Deal Is Feasible and Affordable' (CNN 22 February 2019) https://edition.cnn.com/2019/02/22/opinions/green-new-dealsachs/index.html.

54 Justin Talbot Zorn, Ben Beachy and Rhiana Gunn-Wright, 'A Green New Deal is fiscally responsible. Climate inaction is not' (The Guardian 25 February 2019) https://www.theguardian.com/commentisfree/2019/feb/25/green-new-aocdeal-fiscally-responsible-climate-inaction?CMP=share_btn_tw. 
Deal. ${ }^{55}$ For their part, Republicans have sought to attack and misrepresent the Green New Deal. 56

In this context, Brown's book is a meditation upon what would be the essential characteristics of a Green New Deal. Her work seeks to translate larger philosophical concerns about human rights and climate justice into a practical programme of administrative action and legislative initiatives.

As well as being from Scotland, Brown has close connections to Australia. Australia has endured tumultuous politics over the last decade. For a brief period, the Gillard Government introduced a carbon tax in respect of carbon pollution. The Gillard Government also sought to promote clean technologies through the Renewable Energy Target, the Australian Renewable Energy Authority and the Clean Energy Finance Corporation. However, the carbon pricing regime was dismantled by the subsequent Abbott Government. The Turnbull Government and the Morrison Government have struggled to develop their own climate policies. ${ }^{57}$ As it stands, Australia is currently not on track to meet its Paris Climate Targets. ${ }^{58}$ A number of individual Australian states and territories - such as Victoria, South Australia, and the Australian Capital Territory - have made progress on climate action.

While Australia has struggled to develop a consistent climate policy due to constant changes of leadership over the past decade, its near neighbour New Zealand has embraced an ambitious climate policy. New Zealand Prime Minister Jacinda Ardern enunciated her climate plans to

55 Bill McKibben, 'The Hard Lessons of Dianne Feinstein's Encounter with the Young Green New Deal Activists' (The New Yorker 23 February 2019) https://www.newyorker.com/news/daily-comment/the-hard-lessons-of-diannefeinsteins-encounter-with-the-young-green-new-deal-activists-video.

56 Bobby Lewis, 'How Republicans Have Seen Red Over Ocasio-Cortez's Green New Deal' (The Guardian 20 February 2019) https://www.theguardian. com/environment/2019/feb/20/republicans-alexandria-ocasio-cortez-green-newdeal.

57 Greg Jericho, 'The Government is Not Serious About Reducing Emissions' (The Guardian 25 February 2019) https://www.theguardian.com/comment isfree/2019/feb/26/the-government-thinks-were-idiots-and-is-not-serious-aboutreducing-emissions.

58 Petra Stock, 'Australia Not On Track to Meet Carbon Targets' (Climate Council 21 December 2018) https://www.climatecouncil.org.au/australia-not-ontrack-to-meet-climate-targets/. 
the United Nations in September 2018..$^{59}$ She emphasized that climate ambition must embrace a 'just transition', stressing that 'targets need to be backed up with sound policies and detailed transition planning' ${ }^{60}$ Ardern has also argued that 'a credible and effective rulebook underpinning the Paris Agreement is critical for it to be a fully functioning treaty'. ${ }^{61}$

\section{CLIMATE LITIGATION}

This book also charts new judicial approaches to climate law and policy. There has been a significant rise in climate litigation around the world. ${ }^{62}$ There has been a plethora of climate litigation in the United States. ${ }^{63}$ Mary Christina Wood from the University of Oregon has discussed the important role played by the judiciary in atmospheric trust litigation in the United States: 'The judicial branch has the singular ability to order action before it's too late. ${ }^{64}$ The results of climate litigation have been somewhat mixed thus far. The litigation organized by Our Children's Trust against the federal government over climate inaction is still ongoing. ${ }^{65}$ Climate litigation by the cities of New York, San Francisco, and Oakland against fossil fuel companies have been

59 Jacinda Ardern, 'Speech to the UN on Climate Change' (United Nations 27 September 2018) http://www.scoop.co.nz/stories/PA1809/S00362/ardernspeech-to-un-on-climate-change.htm.

60 Ardern n59.

61 Ardern n59.

62 Umair Irfan, 'Pay Attention to the Growing Wave of Climate Change Lawsuits' (Vox 22 February 2019) https://www.vox.com/energy-and-environment/ 2019/2/22/17140166/climate-change-lawsuit-exxon-juliana-liability-kids.

63 Sabin Center for Climate Change Law and Arnold \& Porter, 'U.S. Climate Change Litigation' http://climatecasechart.com/us-climate-change-litigation/.

64 Mary Democker, 'Before It's Too Late: Mary Christina Wood on Avoiding Climate Disaster' (The Sun February 2019) https://thesunmagazine.org/issues/ 518/before-its-too-late.

65 Juliana v. United States (2016) Case No. 6:15-cv-01517-TC (D. Or), amended complaint https://static1.squarespace.com/static/571d109b04426270152 febe0/t/57a35ac5ebbd1ac03847eece/1470323398409/YouthAmendedComplaint AgainstUS.pdf; Juliana v. United States (2016) 217 F. Supp. 3d 1224; and In Re: United States (2018) 895 F. 3d. 1101, Case 18-71928, United States Court of Appeals for the Ninth Circuit. 
unsuccessful at first instance. ${ }^{66}$ Climate litigation by Nelson Kanuk and others against the state of Alaska has been rejected and dismissed. ${ }^{67}$

In the European Union, there have been instances of dramatic victories in respect of climate litigation. Most notably, the Urgenda climate litigation in the Netherlands has been a remarkable success. At first instance in 2015 the court concluded that the state has a duty to take climate change mitigation measures due to the 'severity of the consequences of climate change and the great risk of climate change occurring'. ${ }^{68}$ The Court of Appeals upheld this finding in 2018.69

In Ireland, there is currently climate litigation on foot by the Friends of the Irish Environment against the Irish government over climate inaction. $^{70}$ It has been argued that the National Mitigation Plan 2017 violated Ireland's Climate Action and Low Development Act 2015, the Constitution of Ireland, and human rights obligations under the European Convention on Human Rights. There are other actions on foot in the European Union.

Historically, there have been many procedural and substantive hurdles to bringing climate litigation in Australia. Nonetheless, in the 2019 case of Gloucester Resources Limited v. Minister for Planning, Preston CJ rejected a proposal for an open cut coal mine. ${ }^{71}$ Amongst other things, the judge took into account the greenhouse gas emissions of the project: 'In short, an open cut coal mine in this part of the Gloucester valley

66 City of New York v. BP Plc et al, U.S. District Court for Manhattan No. 1:18-cv-00182 (2018); and City of Oakland v. BP P.L.C. (2018) 2018 WL 3109726, F. Supp. 3d.

67 Kanuk v. State of Alaska, Department of Natural Resources 335 P. 3 d 1088 (2014); and see Matthew Rimmer, 'Northern Exposure: Climate Change, Indigenous Rights, and Atmospheric Trust Litigation in Alaska' in Matthew Rimmer (ed.), Intellectual Property and Clean Energy: The Paris Agreement and Climate Justice (Springer 2018) 639.

68 Urgenda Foundation v. Kingdom of the Netherlands [2015] HAZA C/09/ $00456689 \mathrm{http} / / / \mathrm{climatecasechart.com/non-us-case/urgenda-foundation-v-kingdom-}$ of-the-netherlands/.

69 The State of the Netherlands v. Urgenda Foundation [2018] C/09/456689/ HA ZA 13-1386 http://blogs2.law.columbia.edu/climate-change-litigation/wpcontent/uploads/sites/16/non-us-case-documents/2018/20181009_2015-HAZA-C0 900456689_decision.pdf.

70 Friends of the Environment v. Ireland (2018) http://climatecasechart.com/ non-us-case/friends-of-the-irish-environment-v-ireland/.

71 Gloucester Resources Limited v. Minister for Planning [2019] NSWLEC 7 (Preston CJ) https://www.caselaw.nsw.gov.au/decision/5c59012ce4b02a5a800b e47f (Gloucester). 
would be in the wrong place at the wrong time.' 72 Preston CJ emphasized the justice dimensions of the project: 'The Project will cause distributive inequity, both within the current generation and between the current and future generations.' 73

The Commission of Human Rights in the Philippines has been investigating whether fossil fuel companies should be held responsible for the climate disasters in that vulnerable country. ${ }^{74}$ There has been discussion as to whether Pacific nations will bring climate litigation against major fossil fuel emitters. ${ }^{75}$

In this book, Brown considers evolution of concepts of human rights, the right to a healthy environment, climate justice, and the rights of nature. At one point in the book, she considers the diversity of emerging new approaches in climate litigation. She suggests that this momentum might provide the potential for new approaches involving intellectual property, technology, and climate change. A future wave of climate litigation may well indeed focus upon matters of intellectual property, technology transfer, and innovation.

Building upon her past work, Brown explores the interaction between intellectual property and competition law. There has been an ongoing problem with energy monopolies and oligopolies. Incumbent companies with investments in oil, coal, and gas - and energy utilities - have been hostile to the emergence of renewable energy. There have been concerns about whether there is a fair marketplace for competition in the energy sector. Professor Tim Wu has highlighted the importance of antitrust law and policy in regulating technology marketplaces. ${ }^{76} \mathrm{He}$ has recommended a vigorous renewal of competition law and policy in order to avoid concentrations of economic and political power. In this context, competition regulators will play an important role - especially as there is a transition in energy technologies.

72 Gloucester [699].

73 Gloucester [696].

74 Ucilia Wang, 'Climate Accountability Probe Brings Philippines Human Rights Hearing to NYC' (Climate Liability News 20 September 2018) https:// www.climateliabilitynews.org/2018/09/20/philippines-human-rights-climate-hearing/.

75 Lisa Cox, 'Vanuatu Says It May Sue Fossil Fuel Companies and other Countries over Climate Change' (The Guardian 22 November 2018) https:// www.theguardian.com/world/2018/nov/22/vanuatu-says-it-may-sue-fossil-fuelcompanies-and-other-countries-over-climate-change.

${ }_{76} \mathrm{Tim} \mathrm{Wu}$, The Master Switch: The Rise and Fall of Information Empires (Alfred A. Knopf 2010); Tim Wu, The Attention Merchants: The Epic Scramble to Get Inside Our Heads (Alfred A. Knopf 2016); and Tim Wu, The Curse of Bigness: Antitrust in the New Gilded Age (Columbia Global Reports 2018). 
There is also a consideration and exploration by Brown of the rise of investor-state dispute settlement and its implications for the regulation of the environment, biodiversity, and climate change. There has been concern that international investment agreements and trade laws will have a deregulatory impact in respect of environmental regulations. In her final chapter, Brown explores whether companies could use investor-state dispute settlement as a means of delaying and blocking environmental action and climate progress. This is not a merely theoretical or idle concern. As I have documented in my own research on the topic, a gas company has used the mechanism of investor-state dispute settlement against a ban on fracking in Quebec. ${ }^{77}$ Likewise, I have examined how TransCanada invoked investor-state dispute settlement against President Barack Obama's decision to block the Keystone XL Pipeline. ${ }^{78}$ Kyla Tienhaara has warned of the dangers of the expropriation of environmental governance through the means of investor-state dispute settlement. ${ }^{79}$ She has expressed fears of a 'regulatory chill in a warming world'. ${ }^{80}$ Andrew Mitchell and James Munro have worried that states' current approach to investor clauses leaves open major unresolved issues for environmental regulation. ${ }^{81}$ Gus van Harten has suggested that the international agreement on climate change - the Paris Agreement 2015 should include safeguards to prevent foreign investors from bringing investor actions against climate change action. ${ }^{82}$

77 Matthew Rimmer, 'The Empire Strikes Back: Fossil Fuel Companies, Investor-State Dispute Settlement, International Trade, and Accountable Climate Governance', in Elizabeth Edmondson and Stuart Levy (eds), Transformative Climates and Accountable Governance (Palgrave 2018) 75.

78 Rimmer n77.

79 Kyla Tienhaara, The Expropriation of Environmental Governance: Protecting Foreign Investors at the Expense of Public Policy (Cambridge University Press 2009).

80 Kyla Tienhaara, 'Regulatory Chill in a Warming World: The Threat to Climate Policy Posed by Investor-State Dispute Settlement' (2018) 7(2) Transnational Environmental Law 1.

81 Andrew D Mitchell and James Munro, 'No Retreat: An Emerging Principle of Non-Regression from Environmental Protections in International Investment Law' (forthcoming 2019) Georgetown Journal of International Law https:// papers.ssrn.com/sol3/papers.cfm?abstract_id=3338055.

82 Gus Van Harten, 'An ISDS Carve-Out to Support Action on Climate Change', Osgoode Hall Law School Legal Studies Research Paper (2015) https://canadians.org/sites/default/files/publications/VanHarten-EN-Mar2016.pdf. 


\section{CONCLUSION}

In conclusion, Professor Abbe Brown's book Intellectual Property, Climate Change and Technology provides a blueprint for future climate action by international institutions, parliaments, and courts. The piece seeks to provide some new philosophical underpinnings for understanding climate change and represents an important scholarly contribution to the greening of intellectual property law and policy. The research seeks to provide inspiration for innovation policy and to provide greater unity and coherence to the growing thicket of climate law and policy. This research is timely and pertinent - given the limited period of time to shift policy course to effectively address the magnitude of the climate crisis. 